\title{
IDENTIFICATION AND ANALYSIS OF SOURCE CONTRIBUTIONS TO THE AIR QUALITY IN THE AMSTERDAM REGION
}

\author{
SÍLVIA COELHO, JOANA FERREIRA, VERA RODRIGUES, SANDRA RAFAEL, \\ CARLOS BORREGO \& MYRIAM LOPES \\ CESAM \& Department of Environment and Planning, University of Aveiro, Portugal
}

\begin{abstract}
Air pollution has become a growing concern in the past few years, with an increasing number of acute air pollution episodes in many cities worldwide. Ozone $\left(\mathrm{O}_{3}\right)$ is a powerful oxidising agent and one of the air pollutants of most concern in Europe. Source apportionment modelling provides valuable information on the contributions of different source sectors and source regions to ozone concentrations. This information can be useful in designing air quality management strategies and in understanding the potential benefits of reducing emissions from a particular source category. In the present work, the Comprehensive Air Quality Model with Extensions (CAMx), with its Ozone Source Apportionment Technology (OSAT), was applied over Amsterdam Region, Netherlands, for the period of $8^{\text {th }}$ to $12^{\text {th }}$ July 2010, when high concentration of ozone were measured in several air quality monitoring stations in the region of Amsterdam. The contributions of different source categories and the NOx/VOC limitation to the ozone formation were quantified. Results indicated a great influence of transboundary transport on the $\mathrm{O}_{3}$ simulated concentrations. The OSAT tool revealed that this is the main factor affecting $\mathrm{O}_{3}$ levels in the area of study, followed by VOC emissions from solvent use and NOx emissions from industry and other sources not individually analysed. $\mathrm{O}_{3}$ formation is slightly more NOx limited than VOC limited.
\end{abstract}

Keywords: ozone, numerical modelling, source apportionment.

\section{INTRODUCTION}

Reduced emissions have improved air quality in Europe, and, for a number of pollutants, exceedances of European standards are rare. However, substantial challenges remain and considerable impacts on human health and on the environment persist. Regarding ozone $\left(\mathrm{O}_{3}\right)$, concentrations above the European Union (EU) $\mathrm{O}_{3}$ target value set by the Air Quality Directive [1] for the protection of human health are still being registered in more than half of the European Member States [2]. Air pollutants released in one area may contribute to or result in poor air quality elsewhere. Moreover, important contributions from intercontinental transport influence $\mathrm{O}_{3}$ and PM concentrations in Europe.

Ozone is a secondary pollutant mainly formed through the complex atmospheric photochemical reactions between nitrogen oxides (NOx) and volatile organic compounds (VOCs) in the presence of sunlight [3], [4]. In the $\mathrm{O}_{3}$ formation under VOC conditions (VOClimited regime), a change in NOx can have little or no effect on tropospheric $\mathrm{O}_{3}$ formation. According to Soret et al. [5], in some cases, a reduction in NOx in a VOC-limited regime can increase tropospheric $\mathrm{O}_{3}$ formation. In the VOC-limited regime, a reduction in VOC is sometimes the only way of reduction in the short term, which would typically be the case in central locations of larger cities. Regarding the rural areas, this seems to be predominantly NOx sensitive. A decrease or increase in NOx may therefore likely cause a reduction or increase, respectively, in the background tropospheric $\mathrm{O}_{3}[6]$.

$\mathrm{O}_{3}$ formation processes and sources are difficult to identify and control due to the non-linear relation with gaseous precursors. Air pollution source apportionment modelling is 
a fundamental tool since it allows for the estimation of $\mathrm{O}_{3}$ concentrations attributable to precursor emissions from specific source groups.

Traditional source apportionment approaches consider the technology that has been responsible for creating the emissions. The ClairCity Project (Citizen Led Air Pollution Reduction in Cities) propose to go beyond this and develop a new perspective of pollution based instead on activities, behaviour and practices that constitute everyday life within the cities which allow to determine the link between pollution and behaviour. Amsterdam region is one of the ClairCity's study regions and thus, it was selected to perform this first overall assessment of the source contribution to the photochemical air pollution in the region. This study focuses on the quantification of the source and transboundary contributions to the $\mathrm{O}_{3}$ levels registered in several air quality monitoring stations, based on the application of the WRF-CAMx air quality source apportionment modelling system, over the Amsterdam region, to a summer period when high levels of $\mathrm{O}_{3}$ were observed.

\section{EPISODE SELECTION}

Since the ozone concentrations depends not only on precursor emissions but also on meteorological conditions, episodes of elevated ozone levels occur mainly during periods of warm, sunny weather [7]. According to the European Environmental Agency (EEA), an ozone episode is defined as follows: "A period of usually a few days up to 2-3 weeks with high ozone concentrations, characterised by daily exceedances of the thresholds set to protect human health. Ozone episodes occur under specific meteorological conditions characterised by large stagnant areas of high pressure. Since the formation of ozone requires sunlight, ozone episodes mainly occur during summer" [8].

Areas of high air pressure (anticyclones) lead to large-scale subsidence, clear skies and increased surface temperatures. These meteorological conditions increase ozone concentrations. Due to prevailing low horizontal and vertical mixing (stagnant conditions), emissions of ozone precursors are slowly dispersed into the atmosphere and chemical reactions lead to ozone formation take place. Summer 2010 in Europe was characterised by these meteorological conditions, with a long period with frequent exceedances between $24^{\text {th }}$ June and $22^{\text {nd }}$ July [7]. Netherlands was one of the many countries across Europe registering exceedances in the ozone information threshold during summer 2010. According to the EEA report [7], on the $8^{\text {th }}$ and $10^{\text {th }}$ July, between $50 \%$ and $75 \%$ of the total monitoring stations registered exceedances of the ozone information threshold, and the number of exceedances was even higher on the $9^{\text {th }}$ July, in more than $75 \%$ of the stations in the country.

The synoptic analysis of meteorological conditions over the case study area allows to identify a high air pressure (anticyclone) in central Europe and a low air pressure (cyclone) over Iceland, on the $8^{\text {th }}, 9^{\text {th }}$ and $10^{\text {th }}$ July. These air masses influence the meteorological conditions in the study area, where high surface temperatures and weak southwest prevailing winds were observed. During the night of $10^{\text {th }}$ to $11^{\text {th }} \mathrm{July}$, the cyclone moves over Netherlands region and the meteorological conditions start changing. Due to this fact, surface temperature starts drooping and the prevailing wind change its direction to east.

According to the above information, the ozone episode selected for this work was the period of $8^{\text {th }}$ to $12^{\text {th }}$ July 2010 .

\section{AIR QUALITY MODELLING APPLICATION}

The air quality modelling system WRF-CAMx, with the $\mathrm{O}_{3}$ source apportionment technology (OSAT), was applied for the evaluation and interpretation of $\mathrm{O}_{3}$ concentrations distributions for the $\mathrm{O}_{3}$ episode chosen in the previous section. 
The WRF model (Weather Research and Forecasting), from the National Center for Atmospheric Research (NCAR) [9], version 3.5., is a next generation mesoscale numerical weather prediction system designed to serve both operational forecasting and atmospheric research needs. CAMx (Comprehensive Air Quality Model with Extensions) [10] is a 3D chemistry-transport model suited for the simulations of the emission, dispersion, chemical reactions, and removal of pollutants in the troposphere based on the integration of the continuity equation for each chemical species on a system of nested three-dimensional grids. The gas-phase photochemistry is resolved through the Carbon Bond (CB05 or CB6) or the SAPRC99 chemical mechanism. CAMx includes a source apportionment (SA) or attribution capability that chemically apportions ozone to boundary conditions and emissions. This approach estimates the contributions from multiple source areas, categories, and pollutant types to the spatial and temporal distribution of ozone in a single model run. It uses multiple reactive tracers to track the contribution of $\mathrm{O}_{3}$ and precursors (NOx and VOC) to model estimated $\mathrm{O}_{3}[10]$, [11]. This is undertaken to identify the dominant source types contributing to the ozone levels. It also allows quantifying the contribution of boundary and initial conditions and investigating whether ozone formation is NOx or VOC limited. The OSAT reactive tracers are adjusted first for $\mathrm{O}_{3}$ destruction, which results in proportional reductions in $\mathrm{O}_{3}$ tracers, then $\mathrm{O}_{3}$ production.

CAMx version 6.30, with its updated OSAT tool [12], was applied over case study region using a two-nesting approach based on a European domain with 0.25 degrees' horizontal resolution and the domain of interest centred in Amsterdam, with 25 by 25 cells, at 0.05 degrees' horizontal resolution (Fig. 1). Meteorological inputs to the chemical simulations

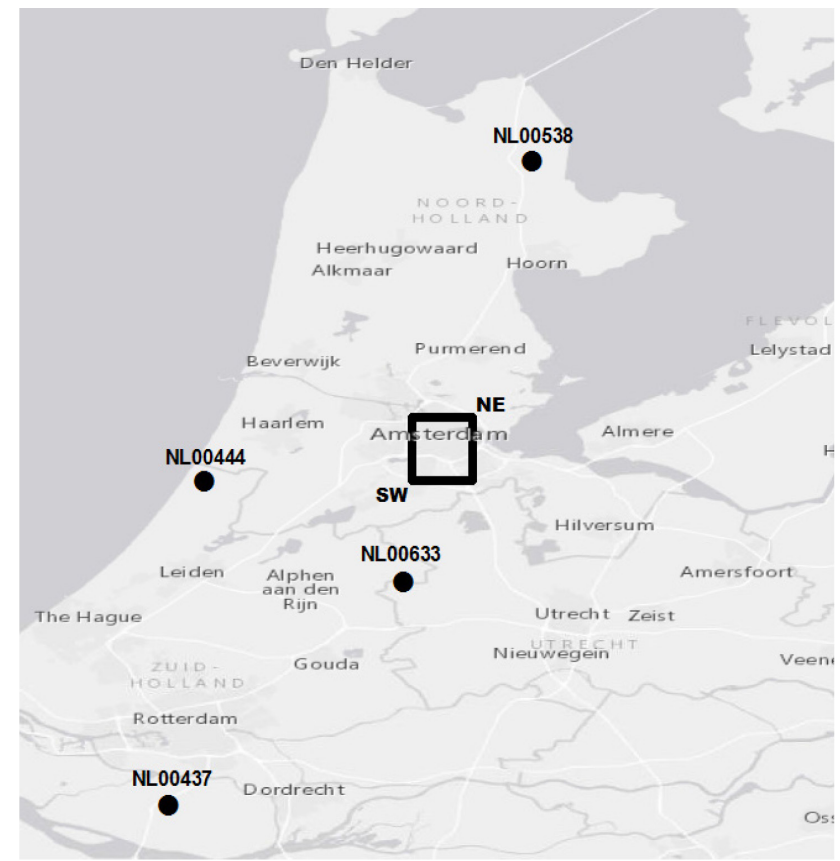

Figure 1: Map of the CAMx nested domain centred in Amsterdam city, at 0.05 degrees' horizontal resolution, with the location of the five receptors (four points: NL00437, NL00444, NL00538 and NL00633; and the area within the black square) considered in the source apportionment application. 
were driven by the meteorological model WRF, forced by ERA-Interim reanalysis data from ECMWF (European Centre for Medium Range Weather Forecast) at 6 hours and 0.75 degrees temporal and spatial resolution respectively. Initial and boundary conditions for the first domain provided by the global chemical model MOZART [13] with a time resolution of 6 hours. Anthropogenic emissions for both domains were taken from the TNO-MACC_II European emission inventory [14] available at a resolution of 0.125 by 0.0625 degrees, and were speciated into the CB6 chemical mechanism species considered in the CAMx simulation [15].

The OSAT application requires the definition of source groups to be tracked and thus the input of extra emission files for each of the groups to be considered. Based on the Netherlands national emission inventory [16] and on the emission sources and amounts of ozone precursors, the main sectors contributing to NOx and VOC emissions in the year under study (2010) are: (i) residential and commercial combustion (13\% to NOx, $9 \%$ to NMVOC); (ii) road transport ( $43 \%$ to $\mathrm{NOx}, 19 \%$ to NMVOC); (iii) industry $(13 \%$ to $\mathrm{NOx}, 33 \%$ to NMVOC); and (iv) solvents' use ( $23 \%$ to NMVOC).

To get results for the period of interest taking into account the modelling system spin-up, the WRF-CAMx model was run for an 8-day period starting on the $5^{\text {th }}$ of July.

\section{ANALYSIS OF RESULTS}

The WRF-CAMx application provided an estimation of how much modelled $\mathrm{O}_{3}$ came from boundaries (BD) and from specific source groups previously defined - residential and commercial combustion (RES), industrial combustion and processes (IND), road transport (TRP), solvents (SOLV) and all the remaining sources (OTH). The results were analysed in terms of the relative contribution of those groups to the $\mathrm{O}_{3}$ concentration simulated for five receptor areas - urban area of Amsterdam (URB), defined by the average of 4 grid cells and the four background monitoring stations NL00437, NL00444, NL00538, NL00633, represented by the respective grid cell location (see Table 1 and Fig. 1). The VOC or NOx limited $\mathrm{O}_{3}$ formation in these five receptors was also analysed.

Table 1: List of receptors (four points and one area, as displayed in Fig. 1) considered in the OSAT application and their respective latitude-longitude coordinate locations.

\begin{tabular}{|c|c|c|c|c|}
\hline Receptor name & \multicolumn{2}{|c|}{$\begin{array}{c}\text { Receptor } \\
\text { abbreviation }\end{array}$} & $\begin{array}{c}\text { Longitude } \\
\left({ }^{\circ}\right)\end{array}$ & $\begin{array}{c}\text { Latitude } \\
\left({ }^{o}\right)\end{array}$ \\
\hline Westmaas-Groeneweg & \multicolumn{2}{|c|}{ NL00437 } & 4.45 & 51.79 \\
\hline De Zilk-Vogelaarsdreef & \multicolumn{2}{|c|}{ NL00444 } & 4.51 & 52.30 \\
\hline Wieringerwerf-Medemblikkerweg & \multicolumn{2}{|c|}{ NL00538 } & 5.05 & 52.81 \\
\hline Zegveld-Oude Meije & \multicolumn{2}{|c|}{ NL00633 } & 4.84 & 52.14 \\
\hline \multirow{2}{*}{ Urban area of Amsterdam $\left(\sim 100 \mathrm{~km}^{2}\right)$} & \multirow{2}{*}{ URB } & SW & 4.85 & 52.30 \\
\hline & & $\mathrm{NE}$ & 4.95 & 52.40 \\
\hline
\end{tabular}




\subsection{Concentration fields}

Fig. 2 presents the $\mathrm{O}_{3}$ concentration fields obtained by the CAMx application for a subset of the simulation period. The maps for the $9^{\text {th }}$ of July show that $\mathrm{O}_{3}$ levels start increasing at 9 am in the study domain due to the transport from the East boundary, and then they are enhanced by local formation. During the night and the morning of next day, $\mathrm{O}_{3}$ concentrations are minima due to the NO-NO 2 reactions and $\mathrm{O}_{3}$ transport towards the Northeast part of the domain. On the $10^{\text {th }}$, at day time, $\mathrm{O}_{3}$ concentration patterns are similar to the day before, although reaching lower maxima. At night, from $10^{\text {th }}$ to $11^{\text {th }}$ of July, the $\mathrm{O}_{3}$ plume reflects the modification of meteorological conditions and the wind direction change, moving to the southwest of the domain.

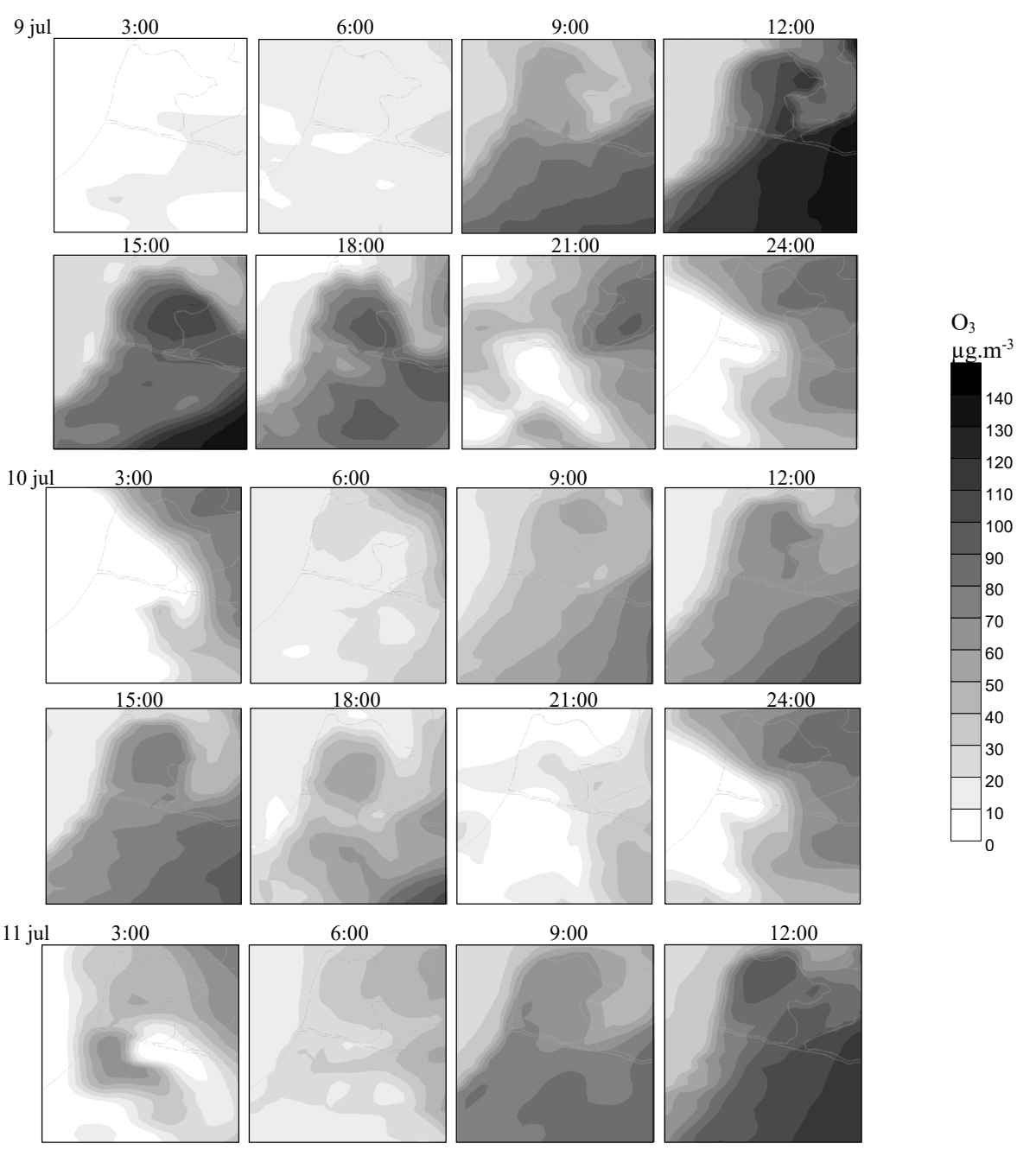

Figure 2: $\quad \mathrm{O}_{3}$ concentration fields $\left(\mu \mathrm{g} . \mathrm{m}^{-3}\right)$ simulated by CAMx from the $9^{\text {th }}$ of July 2010 at 3:00 am to the $11^{\text {th }}$ of July 2010 at 12:00 am, every 3 hours. 


\subsection{Source contribution analysis}

The contribution of each source group in each receptor for the simulation period is analysed in Fig. 3. The average contributions for each simulation day (Fig. 3(a)) reveal that the major contribution is from initial/boundary conditions, highlighting the importance of transboundary pollution to the $\mathrm{O}_{3}$ formation in the study region. This background/ transboundary effect is more notorious on the first day and last days analysed. Note that the entire simulation started on the $5^{\text {th }}$ of July and thus on the $8^{\text {th }}$ of July there are no initial conditions' affecting the results. Fig. 3(a) plots also show a similar behaviour for all the

(a)
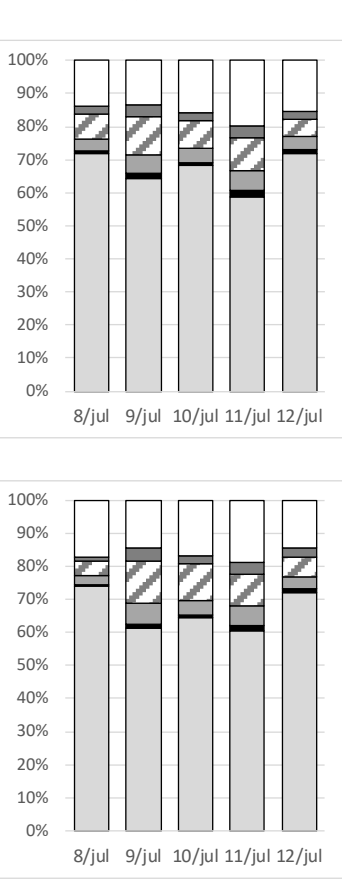

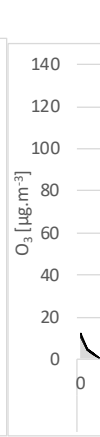

(b)

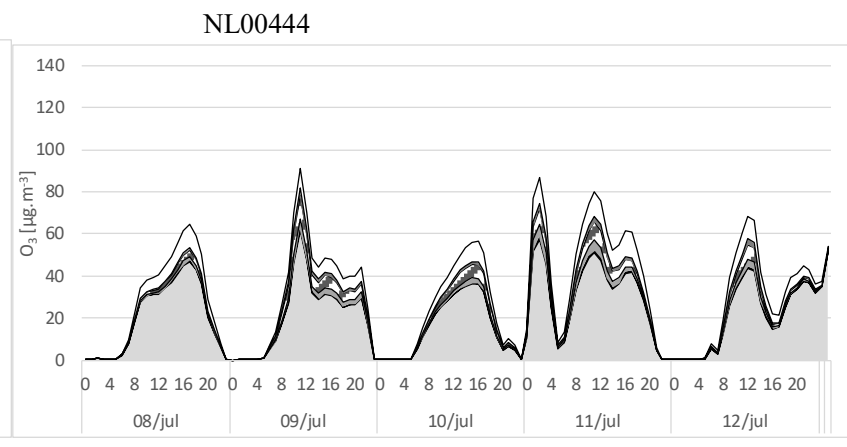

NL00437

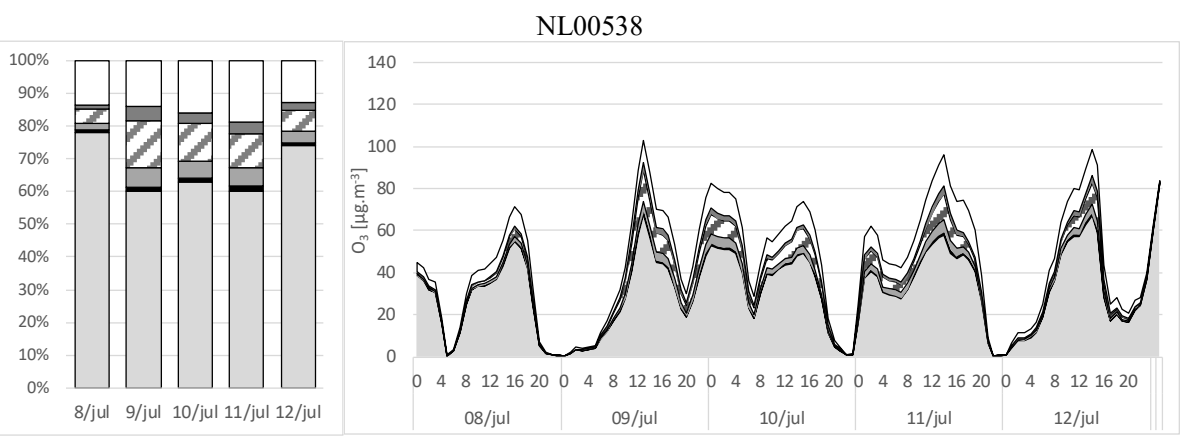

Figure 3: (a) Daily average contributions, of each one of the groups tracked with OSAT, to the total $\mathrm{O}_{3}$ concentration modelled for each of the 5 receptors for the period 8-12 July 2010; (b) Hourly contributions for each simulation day and receptor. 
(a)

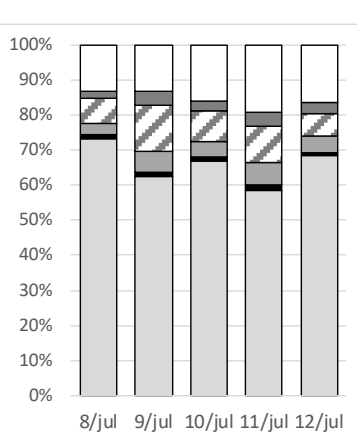

NL00633

(b)

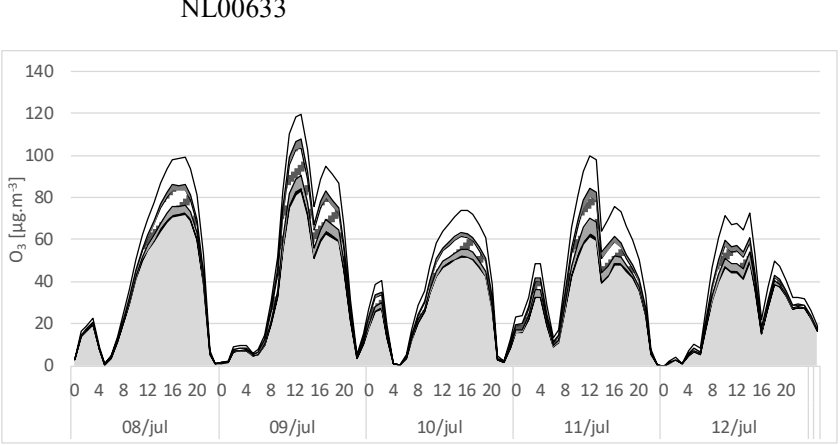

URB
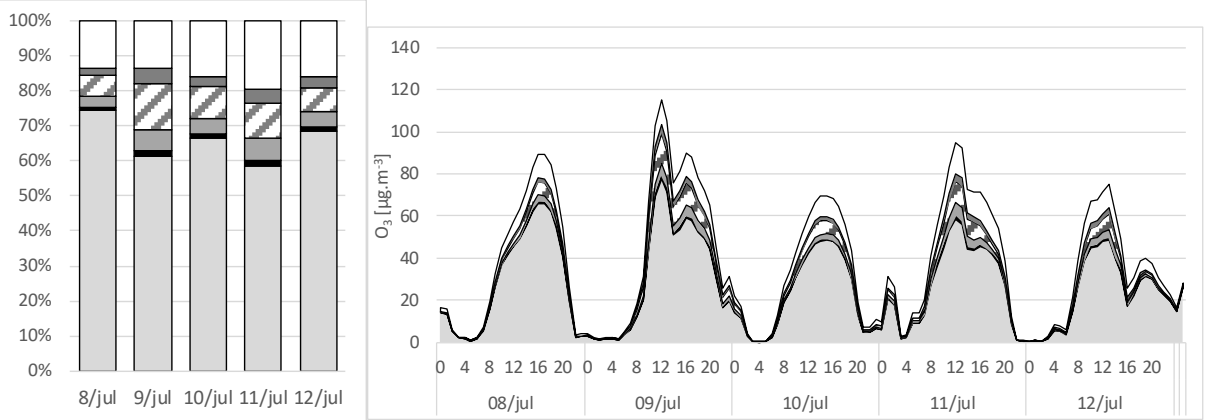

$\square$ IC+BC $\square$ RES $\square$ IND $\square$ SOLV $\square$ TRP $\square$ OTH

Figure 3: Continued.

receptors, as expected from the boundary conditions contribution between 60 and $75 \%$. Among the source groups individualized in the analysis the use of solvents (SOLV) has the greater influence on $\mathrm{O}_{3}$ modelled concentrations, followed by industry (IND) and transport (TRP). The contribution of other sources not discretely tracked in OSAT varies between 15 and $20 \%$.

The highest contribution of precursor emissions is verified for the $9^{\text {th }}$ and $11^{\text {th }}$ of July, leading also to higher maximum $\mathrm{O}_{3}$ concentrations, as it can be observed in the plots of Fig. 3(b). Regarding the time series of contributions, maximum $\mathrm{O}_{3}$ concentrations are simulated for the NL00437 and NL00633 receptors, both located South of Amsterdam urban area, and occur at mid-afternoon. During the night, in most of the simulated days $\mathrm{O}_{3}$ levels drop down due to consumption by NOx. Moreover, on the $10^{\text {th }}$ to $11^{\text {th }}$ night, a peak of $\mathrm{O}_{3}$ is observed in all receptors, as a consequence of the meteorological variability and wind direction change as already referred. 


\subsection{NOx-limited/VOC-limited regime}

The $\mathrm{O}_{3}$ production limited by VOC or NOx is analysed in Fig. 4 for each day and receptor. Globally both NOx and VOC limit the $\mathrm{O}_{3}$ formation. However, in some days $\left(8^{\text {th }}, 11^{\text {th }}\right.$ and $12^{\text {th }}$ ) the NOx contribution is higher in all receptors (between 54 and 56\%).

These results, together with the source apportionment outcomes, are particular important for the planning and definition of the most efficient mitigation measures regarding $\mathrm{O}_{3}$ concentrations. This planning requires not only the recognition/identification of the area and activity sources, but also the $\mathrm{O}_{3}$ 's precursor specie to be focus on.

\section{NL00437}
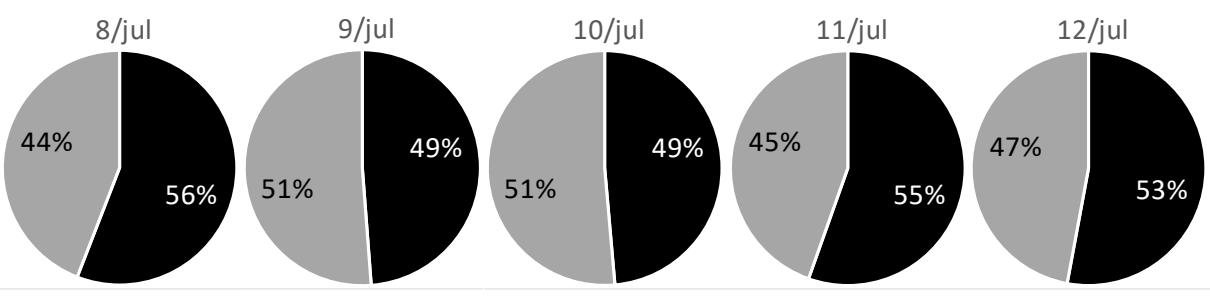

\section{NL00444}
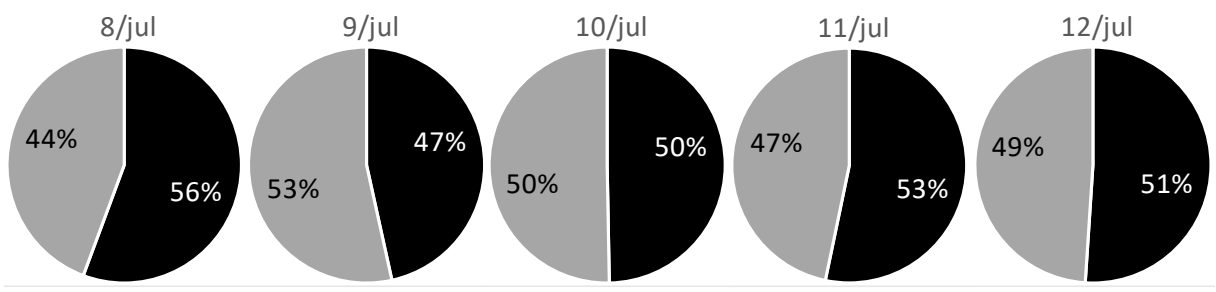

NL00538
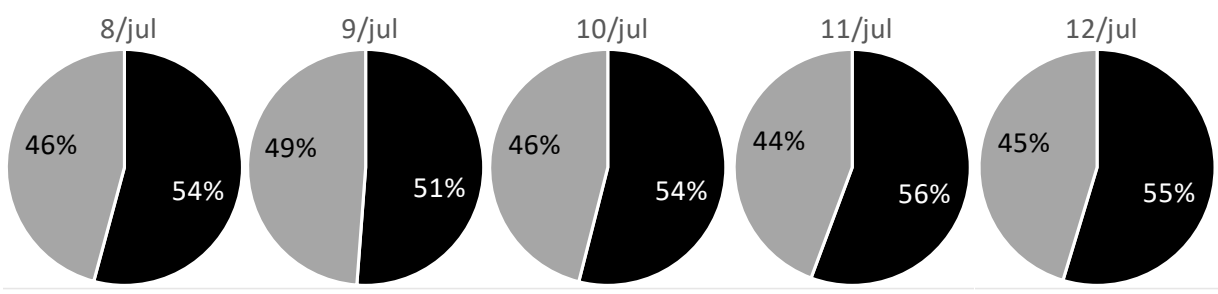

NL00633
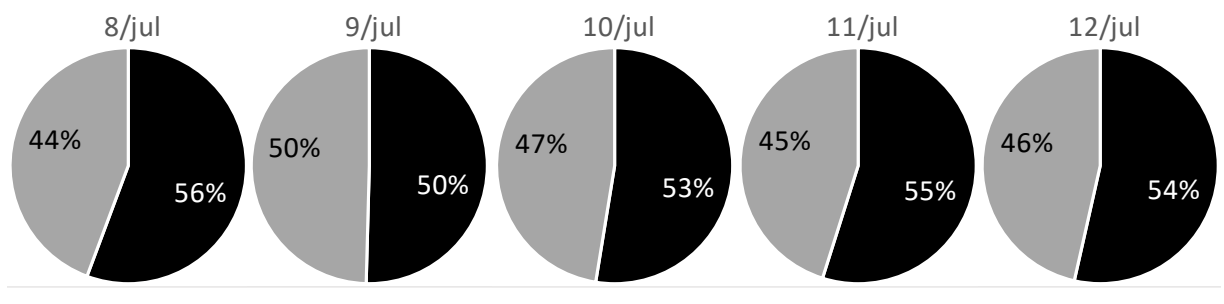

- NOx-limited - VOC-limited

Figure 4: NOx limited /VOC limited regime for each simulation day and receptor. 


\section{CONCLUSIONS}

In this work, an ozone episode was selected and studied, aiming to assess the contribution of different types of emissions sources to the ozone formation in the Amsterdam region, by air quality modelling and source apportionment tools.

The ozone source apportionment application allowed to investigate the contribution of boundary conditions and emissions of precursors to ozone production in the region of Amsterdam. Results revealed that the major contribution to the ozone levels simulated by CAMx model is from transboundary transport, similarly to what was concluded in previous source apportionment studies [17].

Among the anthropogenic source groups individualized in the analysis the use of solvents has the greater influence on $\mathrm{O}_{3}$ modelled concentrations, followed by industry.

For the selected episode and in most of the days simulated the NOx contribution for ozone formation is higher (between 54 and 56\%) than VOC contribution in all receptors.

The outcomes of this study will support the research being carried out in the ongoing ClairCity project, namely in what concerns the identification of the main source activities and source areas contributing to the high levels of $\mathrm{NO}_{2}$ and $\mathrm{O}_{3}$ registered in Amsterdam region as well as in other case studies.

These results, focused on emissions from activities/sources are a first approach and an important information to understand the contribution of individual sources for regional air pollution. Future developments under ClairCity project include a new perspective that intends to evaluate the impact of citizen's behaviour on air pollution; i.e., considering the disaggregation of source emissions (for example transport) by citizen's behaviour patterns in the everyday life (transport to school, to work, to shopping, ...). The ultimate goal is to improve people's knowledge, to influence and to change citizen's behaviour and promote a more participative society on solving urban air quality problems and reducing carbon footprint.

\section{ACKNOWLEDGEMENTS}

This work was partially supported by the ClairCity project. ClairCity has received funding from the European Union's Horizon 2020 research and innovation programme under grant agreement 689289. The authors would like to thank Hugo A. C. Denier van der Gon and Jeroen J. P. Kuenen for the access and use of the TNO MACC_II European Emission Inventory. The authors would also like to acknowledge the financial support through national funds from FCT - Science and Technology Portuguese Foundation for the Post Doc grant of J. Ferreira (SFRH/BPD/100346/2014) and the PhD grant of S. Rafael (SFRH/BD/103184/2014).

\section{REFERENCES}

[1] European Union (EU), Directive 2008/50/EC of the European Parliament and of the Council of 21 May 2008 on ambient air quality and cleaner air for Europe. Official Journal of the European Union, L152, pp. 1-44, 2008.

[2] European Environmental Agency (EEA), Air quality in Europe - 2016 Report, EEA Report No 28/2016, 2016.

[3] Sillman, S., The relation between ozone, $\mathrm{NO}_{\mathrm{X}}$ and hydrocarbons in urban and polluted rural environments. Atmospheric Environment, 33, pp. 1821-1845, 1999.

[4] Seinfeld, J. \& Pandis, S., Atmospheric Chemistry and Physics: From Air Pollution to Climate Change, 2nd ed., John Wiley \& Sons, Inc.: Hoboken, NJ, 1232 pp., 2006.

[5] Soret, A., Guevara, M. \& Baldasano, J.M., The potential impacts of electric vehicles on air quality in the urban areas of Barcelona and Madrid (Spain). Atmospheric Environment, 99, pp. 51-63, 2014. 
[6] Bach, H., et al., Services to assess the reasons for non-compliance of ozone target value set by Directive 2008/50/EC and potential for air quality improvements in relation to ozone pollution. Final report. ECORYS, 2014.

[7] European Environment Agency (EEA), Air pollution by ozone across Europe during summer 2010 - overview of exceedances of EC ozone threshold values for AprilSeptember 2010, 38 pp., 2011.

[8] European Environment Agency (EEA), Environmental Terminology and Discovery Service, http://glossary.eea.europa.eu/EEAGlossary/O/ozone episode. Accessed on: 12 Feb. 2017.

[9] Skamarock, W.C., et al., A Description of the Advanced Research WRF Version 3. NCAR/TN-475+STR Ncar Technical Note, 2008.

[10] ENVIRON, User's Guide Comprehensive Air Quality Model with Extensions Version 6.30.Ramboll Environ, Novato, CA, 2016.

[11] Baker, K., Emery, C., Dolwick, P. \& Yarwood, G., Photochemical grid model estimates of lateral boundary contributions to ozone and particulate matter across the continental United States. Atmospheric Environment, 123, pp. 49-62, 2015.

[12] Yarwood, G. \& Koo, B., Improved OSAT, APCA and PSAT Algorithms for CAMx. Final report prepared for the Texas Commission on Environmental Quality, Austin, Texas (Aug. 2015). Prepared by Ramboll Environ, Novato, CA, 2015.

[13] Emmons, L.K., et al., Description and evaluation of the Model for Ozone and Related Chemical Tracers, version 4 (MOZART-4). Geoscientific Model Development, 3, pp. 43-67, 2010.

[14] Kuenen, J.J.P., Visschedijk, A.J.H., Jozwicka, M. \& Denier van der Gon, H.A.C., TNO-MACC_II emission inventory; a multi-year (2003-2009) consistent highresolution European emission inventory for air quality modelling. Atmospheric Chemistry and Physics, 14, pp. 10963-10976, 2014.

[15] Yarwood, G., Jung, J., Whitten, G.Z., Heo, G., Mellberg, J. \& Estes, E., Updates to the Carbon Bond Mechanism for Version 6 (CB6). 9th Annual CMAS Conference, Chapel Hill, Oct. 2010.

[16] Jimmink, B.A., et al., Informative Inventory Report 2016: Emissions of transboundary air pollutants in the Netherlands 1990-2014. National Institute for Public Health and the Environment, 2016.

[17] Borrego, C., et al., Air quality plan for ozone: an urgent need for North Portugal. Air Quality, Atmosphere and Health, 9, pp. 447-460, 2016. 